FACTA UNIVERSITATIS

Series: Physical Education and Sport, Vol. 17, No 2, 2019, pp. 205 - 220

https://doi.org/10.22190/FUPES190523021S

Professional article

\title{
PUBLIC-PRIVATE PARTNERSHIP IN THE FUNCTION OF INCREASING THE QUALITY OF SCHOOL SPORTS FACILITIES
}

\author{
UDC 37.013.3(497.11)
}

\author{
Suzana Subić $c^{1}$ Zoran Simonović ${ }^{2}$ \\ ${ }^{1}$ 10th Gymnasium School “Mihajlo Pupin”, Belgrade, Serbia \\ ${ }^{2}$ Institute of Agricultural Economics in Belgrade, Belgrade, Serbia
}

\begin{abstract}
The aim of the paper is to indicate that for the sustainable development of school sports infrastructure it is necessary to create conditions that should clearly be defined in the mutual rights and obligations of all participants in the process of construction, use and maintenance. This would be achieved through public-private partnerships between the state and the private sector. This paper is based on the experiences of some of the European Union countries, which have solved the problems of building, upgrading, equipping and maintaining school sports facilities through public-private partnership projects, on the legal regulations contained in the Green Paper on Public-Private Partnership, as well as the Law on Public-Private Partnership and Concessions in the Republic of Serbia. Certainly, the desire to improve the quality of educational services, on the one hand, and lack of money in the budgets of central and local governments, on the other, imposes the need to research this type of business cooperation and project financing. This paper also points to the need for more detailed research into the possibilities of applying public-private partnership, through projects in the field of education and its effects on increasing the quality of the physical education teaching. The paper also reviews the complexity of the implementation of publicprivate partnership in traditional educational frameworks, due to the complexity of the relationship between the two partners who impose different interests.
\end{abstract}

Key words: School Sports Facilities, Public Private Partnership, European Union, Republic of Serbia

Received May 23, 2019/ Accepted October 13, 2019

Corresponding author: Suzana Subić

10th Gymnasium School "Mihajlo Pupin”, St. Antifašističke borbe 1a, 11000 Belgrade, Serbia

Phone: +381 113114142 •E-mail: suzana.s.nikolic@gmail.com

C 2019 by University of Niš, Serbia | Creative Commons License: CC BY-NC-ND 


\section{INTRODUCTION}

School sports facilities are an integral part of the formal education of every child. These spaces should enable and improve the development of the potential of each student, and provide a student and teacher with a comfortable, safe and healthy environment in order to achieve the best possible results. School sports facilities, as part of the community in which they are located, must be able to serve the community as a whole. Development should go in the direction of upgrading existing capacities, building new facilities, equipping and maintaining, in accordance with the needs of physical education teaching and the needs of the local community, and in accordance with the experiences of the European Union countries (Šuput, 2009). School sports facilities are, apart from the competence of teachers, a necessary condition for the successful implementation of physical education. Without proper conditions we cannot expect positive results, not the realization of plans and programmes of physical education to their full extent (Matić, Bokan, Bokan, \& Perković, 1990, in Zrnzević \& Zrnzević, 2018).

The public-private partnership in the function of increasing the quality of school sports facility services should be considered as one of the available forms of financing, which must be based on clearly defined rules, needs and plans for the development of the entire educational system and sports in the Republic of Serbia. In education, the benefit of public-private partnership is above all to relieve public budgets of large-scale investments, to quickly and efficiently solve problems, increase the quality of facilities and equipment, and switch to one-shift schoolwork.

The model of public-private partnership (hereinafter referred to as PPP) is based on the idea of continuous development and finding more efficient ways to provide public infrastructure and provide better services to citizens. There is no harmonized definition that can include PPP. The European Commission's guidelines for a successful PPP (European Commission, 2003) define it as a "partnership between the public and the private sector for the purpose of realizing a project or services traditionally provided by the public sector", and they are characterized by the division of investments, risks, responsibilities and profits among partners. In the Green Paper of the European Commission (European Commission, 2003), PPP is defined as a partnership that relates to forms of public-private cooperation in order to ensure the financing, construction, renovation, management and maintenance of some infrastructure or the provision of services. In other words, making a public-private partnership contract should contribute to the stimulation of the economy, the faster development of infrastructure and public services provided by the public sector in order to meet public needs, which implies cooperation between the private and the public sector (Građanske incijative, 2013). Basically, we can say that PPP represents various types of cooperation between the public and private sectors, which join their resources in order to respond to different requirements related to the provision of public services. In order for the state not to do everything on its own and bear all the risks, it gives a chance to the free economy that takes on itself a part of its tasks and responsibilities. The public sector and private investments function in the long term and together according to this organizational model in the construction of public infrastructure. Joint investments are planned, and common risks are accepted. Given that both partners need to profit, the public sector will receive the necessary infrastructure with lower costs of participation, and private investors will create a new field of action, which will bring them new resources through their skills and competences (Nischwitz \& Andreas, 2019). This type of partnership, between local or central governments and private companies is most commonly established in sectors such as (Terzić, 2013): 
transportation, waste disposal, water and electricity supplies, health and education. In particular, the cooperation between the public and the private sector is most often applied in the financing of capital projects of public importance, such as: highways, road facilities (bridges, tunnels), railways, ports, airports, gas pipelines, refineries, power plants, social infrastructure (hospitals, schools, sports facilities, social facilities with different purposes for certain categories of population), communal infrastructure (water supply network, waste disposal) and facilities used by government institutions.

In order to be considered a PPP project, the European Commission Green Paper gives the main characteristics that a project must have, which is generally accepted by all economically developed European countries. According to the Green Paper of the European Commission, PPP can have two forms: contractual and institutional. The contractual form can be modeled with elements of a concession, such as the case of public transport in Norway (although not one of the member countries, Norway closely cooperates with the European Union), specifically in Oslo. The private sector invested money in the purchase and maintenance of city buses, and the city left the funds from the sale of tickets to a private company for a certain period of time. The second form is institutional, as is the case in England where a private partner charges the delivery of a public service from a public partner in the form of a lease (European Commission, 2004). Many schools in England function according to this model, in such a way that the state and the city or local selfgovernment is obligated to the private partner to return in the long term the funds invested in school facilities, which students use and do not pay. After the expiration of the agreed time contract, the facilities are returned to the jurisdiction of the local self-government or city.

Though its realization it is considered to have a much longer history, but the PPP model, as a matter of interest to the professional and scientific public, is rising in the countries of the European Union after the 1990s. On the other hand, this model of cooperation is in our country only in the beginning. Though it should not be forgotten that the concession in the Republic of Serbia was even present in the nineteenth century, when the French company for exploitation of the Majdanpek mine got a 30-year concession. Later on, the city of Belgrade made a contract with the Italian company for the performance of tram traffic (Biblioteka Narodne skupštine, 2011).

In order to find ways for local, as well as republic authorities, to provide money for financing infrastructure projects and public services, it came to public and private sector cooperation, i.e., finding private partners. Private partners can be private entities, legal entities and natural persons (Biblioteka Narodne skupštine, 2011). Bearing in mind the fact that one of the necessary conditions for the full membership of the Republic of Serbia in the European Union is also the construction of infrastructure in all segments, the construction of public and social institutions, the improvement of public services and the achievement of standards in accordance with long-term development plans and guidelines prescribed by the European Commission, efficient use of PPP projects can be a key condition for economic growth and economic development (Prokopović, 2014).

School sports facilities are an integral part of sports and school infrastructure. These spaces should enable the education of each child and improve the development of potentials of each student. They must provide a student and teacher with a comfortable, safe and healthy environment in order to achieve the best possible results. School sports facilities are also part of the wider community in which they are located, and they must be taken care of. Development should go in the direction of upgrading existing capacities, building new facilities, equipping and maintaining, in accordance with the needs of physical education teaching and the needs of 
the local community. Bearing in mind that investments are the basic material factor of economic and social development, it depends to a large extent on their size, structure and the efficiency of investments how and to what level the basic issues of the development of school sports facilities of each school, primary or secondary, will be solved. These issues mainly concern the creation of opportunities for each school to have appropriate sports facilities for teaching physical education and school sports, well-equipped and maintained appropriate spaces, thus creating the conditions for high-quality educational work.

Lack of financial resources and insufficient investments can be an objective obstacle to the full realization of the prescribed curricula. Also, the limiting factor may be the lack of real development programs and the lack of functionality and the inability of those who need to take care of these facilities.

Given that the budgets of central and local governments are limited, and as a rule, there are insufficient funds for the simultaneous implementation of numerous capital projects of public importance, the need for finding new opportunities for financing problems in school infrastructure is imposed. Some of the forms of PPP can be used to improve the quality of education services through the construction, equipping and maintenance of school sports facilities. By applying various methods of association of the public and private sector in education, there is a possibility of the equal development of school sports facilities in all local communities. The partnership between the public and the private sector in the European Union has also implemented many projects related to school facilities. For the successful implementation of these projects, it is necessary to adopt appropriate principles that need to define partnerships within the PPP, relying on the Green Paper of the European Commission (HM Treasury, 2018). The main reason for making clear guidelines is to encourage the rebuilding of existing and building new facilities of public interest, such as schools, sports facilities, kindergartens, etc. Through the implementation of PPP projects, it is especially important to pay attention to savings, service quality and the environment.

As we will show in the continuation of the research, some of the member states of the European Union (including England) have resolved problems in the education sector through PPP projects, but in the Republic of Serbia for now there are no legal possibilities to solve problems in educational institutions in this way. Accordingly, the paper points to the need to change the legislation, which would create the conditions to encourage cooperation between the public and private sectors in order to improve the quality of services in school sports facilities.

The aim of the paper is to indicate that for the sustainable development of school sports infrastructure it is necessary to create conditions that should be clearly defined in the mutual rights and obligations of all participants in the process of construction, use and maintenance. This would be achieved through public-private partnerships between the state and the private sector.

\section{THEORETICAL CONSIDERATIONS OF THE PROBLEM}

Spaces and their equipment are a significant factor in creating conditions for the realization of educational process in physical education and school sports, and improving the overall development of sports. Providing the necessary, modern equipped space is the basic precondition for quality work with young people. In order to fully implement all the requirements and enable the implementation of new achievements, these factors must be 
based on planned development and improvement. Also, it is important to take into consideration the quality standards of the process, outcomes and working conditions.

School sports facilities are equipped with a training area or a surface that enables the teaching of physical education and school sports to a class with several different contents. The facility for teaching physical education must meet the needs of the school, at the maximum load, of the appropriate school course, with the provision of pedagogical, hygienic, economic and material conditions.

Good material conditions do not just mean the existence of sports halls and outdoor gyms. In order to be able to perform physical activity in these areas, it is necessary to satisfy certain elements, such as (Subić, 2016):

- floor surfaces;

- heating and ventilation system;

- lighting (artificial and natural);

- maintenance of outdoor gyms;

- existence of necessary devices and equipment.

School sports facilities should, above all, be safe to use, accessible to every student and meet hygiene-technical norms in every respect. Regular maintenance of the space and equipment necessary in the realization of teaching is a priority for their preservation, which increases their lifetime and reduces financial investment. The most common problems that occur in this case are (Nikolić, 2010):

- personnel-organizational;

- material-financial.

Financial resources represent a limiting factor in the construction, upgrading, maintenance and equipping of school halls. The economic crisis of the last decades has affected the reduced investment of state and business entities in school sports facilities and their maintenance.

Investments related to school sports facilities may have the following character (Nikolić, 2010):

- adaptation (adaptation to needs, without significant changes in the building);

- changes (adaptation to needs, including significant changes in the building);

- enlargement (adaptation to needs, in school and local community, by building additional components);

- construction (completely new buildings that meet the prescribed standards and norms);

- equipping.

Schools that have the appropriate school sports facilities should properly maintain these spaces, respecting the basic standards of hygiene and cleanliness. Regular and proper maintenance of facilities greatly reduces costs. Due to irregular investment, these facilities become neglected, which reduces the functionality of the space itself. Maintenance of facilities is significant, on the one hand, for the hygiene, safety and comfort of their users, and on the other hand to ensure and extend their lifetime.

In a survey conducted in 2013/2014 (Subić, 2016), out of 212 schools surveyed, 39 schools (18.40\%) received new facilities; 22 schools (10.38\%) received new sports halls, of which 4 schools received a balloon hall and 1 school received a hall for corrective gymnastics, and 20 schools (9.43\%) received new outdoor sports fields.

In addition to the universal outdoor fields where sports activities from handball, basketball, volleyball and football can be realized, 3 schools were given tennis courts and 2 schools received mini-pitches. 
Out of the total of 39 schools that received new sports facilities, 29 are elementary schools $(74.36 \%)$, and the remaining 10 are secondary schools $(25.64 \%)$.

When it comes to reconstruction, investments were made in open and closed spaces, and accompanying facilities in 40 schools (18.87\%). Funds are primarily allocated in order to increase the quality of the existing school sport infrastructure, in order to provide better conditions for children and other users.

Apart from the reconstruction, a certain number of 40 schools mentioned had another type of investment:

- 8 schools $(21.05 \%)$ received new sports facilities;

- 2 schools $(5.26 \%)$ have modernized existing sports fields;

- 2 schools $(5.26 \%)$ had an extension on existing facilities;

- 6 schools (15.79\%) stated that investments were also made in maintaining existing capacities.

The modernization of school sport infrastructure refers to realized investments in 11 schools (5.19\%), primarily activities related to the installation of lighting in sports grounds or tartan tracks. In addition to this type of investment, 2 schools also financed the upgrading and expansion of the existing capacities for the realization of teaching in physical education.

The largest number of schools, 60 (28.30\%) of them, invested in maintaining existing capacities for the realization of physical education. This was definitely predictable, as it is a matter of smaller financial resources that schools can provide more easily. Among the schools which have invested in maintenance of existing capacities, there are also 6 schools $(10.00 \%)$ that had reconstruction of the existing school sport infrastructure and 4 schools $(6.67 \%)$ that received new sports facilities.

Investments in new sports equipment and requisites were made in 32 schools $(15.09 \%)$. This small number of schools, out of 212 surveyed schools, shows the poor offer of necessary funds for successful teaching of physical education. This is the fact that comes out especially if it is known that first of all a ball, a mat and a jumping rope are needed per two students, and the equipment and requisites for their safety must be regularly changed and maintained.

After this analysis, we have come to the conclusion that 77 schools $(36.32 \%)$ have not registered investments in school sport infrastructure in the last ten years (including the requisites necessary for the realization of physical education classes).

Analysis of the collected data also shows that the funds that schools invested in facilities and equipment in order to improve the working conditions of their users come in the majority of cases from the budget of the local self-government unit, in 97 schools (45.75\%).

The worst situation has been proven to be in branch schools. The problem of investing in school halls and sports grounds in branch schools is reflected in a small number of students and the lack of necessary information on the trend of students' enrollment in the coming school years. Observing central and secondary schools, the analysis of the results points to the presence of non-planned investing in facilities aimed at the realization of physical education teaching, without paying attention to the actual capacities of the school. This situation, on the one hand, results in huge facilities whose capacities are not used, while on the other hand, there are schools with a large number of students who attend physical education teaching in school sport facilities of inadequate dimensions and with limited possibilities. A large number of central schools in the Republic of Serbia still do not have a gymnasium (Subić, 2016), and therefore, they pay a relatively high price to sports centers for physical education requirements. Previous research suggests that schools are unequally equipped with the spaces for physical education 
teaching. Such a state of the halls and outdoor gyms does not provide equal conditions for all children, as well as the full realization of the prescribed teaching contents. It is necessary that each school have the minimum prescribed space for teaching physical education and school sport. Without adequate space, which is well equipped, there is no creation of conditions for educational work.

Apart from problems with the spaces themselves, there is also the problem of their equipment. In a large number of schools, this equipment is obsolete, unsafe for use, and the number of requisites is small compared to the number of users. Lack of equipment excludes certain teaching content from realization and makes it difficult to work with classes with a large number of students. Some teaching content is almost not realized.

At constructing gymnasiums and outdoor training halls and maintaining and equipping them according to the PPP principle, the state can increase the quality of service for students in teaching physical education without major financial investments.

We need to recall that many sport facilities that include school facilities for physical education in Europe have come from PPP projects, such as the Wembley Stadium in London or Stade de France in Paris or a new national stadium in Romania, as well as many sports halls in schools in Croatia (Produkcijska grupa Mreža, 2013). Varaždin County has launched projects to build two schools and fifteen school sports halls, and upgrade 27 school facilities, all based on the PPP model. The basic goal of building and upgrading schools and school sports halls in the Varaždin County was to provide space for various development programs for students and to enable the organization of one-shift teaching, better planning and school management, as well as the equal distribution of schools and school sports halls throughout the County (Alibegović, 2010). The Hungarian Government has proposed the program "Sport XXI", in which around 169 swimming pools, sports halls and other sports facilities will be built in municipalities that did not have adequate conditions. The Ministry of Local Government, which is in charge of sports, proposed a program that included $30-50 \%$ of budget subsidies to municipalities to pay regular fees to private partners. A private partner would be at risk of construction and the risk of availability. However, most of the municipalities could not pay fees to their private partner even with subsidies, and they had to find other traditional financial solutions. Of the 133 projects that were considered in the period between 2003 and 2006, only 30 of them concluded the contract (Jokaj, 2010).

Previous contracts made by schools in the Republic of Serbia with private persons about the construction of balloon halls, tennis courts and the renting of school sports facilities were mostly without any control by the state and often at the expense of schools, i.e. students who use little space or do not use it at all in the realization of physical education. The schools addressed the Republic Property Directorate of the Republic of Serbia, asking for a basic consent for the provision of school sports facilities and other spaces for rent, referring to Article 22, Paragraph 2 of the Law on Public Property. Ministry of Education, Science and Technological Development does not publicly promote such a relationship to state property but does not prohibit it. The state must make an appropriate concept for its property, and determine the cost of school space, which will vary from school to school and will depend on various factors, but it would be good to know the lowest and highest price. A state-regulated attitude towards the property could increase the part of the resources the state invests in schools. It should not be forgotten that part of the funds collected in this way must also remain in schools. Schools that receive funds by renting their own spaces must not show them as income but find other ways that allow them to dispose of these funds. As part of a doctoral thesis, the author addressed to 
the Directorate of Property of the Republic of Serbia to find out whether there is a record of schools that gave their space to private persons for the construction or installation of sports facilities. They have answered that there are no such records. The state must find the most suitable way to regulate this area legally, to be transparent where the money goes and who has the money. It is important that issues related to school sports facilities are not completely left to the decisions of school boards and directors.

Bearing in mind the fact that the PPP model in the European Union is one of the most used in the construction, equipping and maintenance of school facilities, our state could, in the best possible way, create conditions for successful implementation of some of the PPP models in our education system.

Through PPP projects in education, the necessary funds for the realization of physical education, school sports, maintenance and equipping of facilities can be efficiently provided in the fastest and most economical way, provided that this type of financing becomes more cost-effective than the traditional investment model.

\section{MODELS OF FINANCING}

How to achieve a better model of financing, which would give public support to sports facilities is one of the more important questions for which an answer is sought, both in the countries of the European Union (including England), and in our country.

In England, the financing of sports facilities and their quality are accompanied by visible oscillations. Due to the decline and marginalization of physical education in schools, the English government had to intervene. Education through physical education is integrated into the broader social concept. The goals of the English government, set up in the 2000s, were one of the most important for the development of physical education and school sports, as during this period the central government invested heavily and through public funding provided a new and extensive school sports infrastructure (Jung, Pope, \& Krik, 2016). Although there are cases in which sports facilities have to be closed due to an unsustainable financial situation, the English government has continued with the policy of financing sports infrastructure. The strategic plan envisages that the state transfers certain funds from local authorities to local governments, especially where new sports facilities are needed. In addition, the new Ministry of Finance program will allow sports facilities to be used both by students and local sports clubs. Since the English government does not have precise information, nor a financial investment of local government units is made in sports infrastructure in agreement with it or certain sports institutions, it is necessary to carry out planning by the Sport England (Sport England, 2018), the institution that creates conditions for everyone to do physical activity regardless of age, opportunities and gender. In this way, a high quality of information on types of investments will be ensured throughout the country and it will be determined where the sports facilities are needed in order for potential strategic planning to be realized. Sport England will require local governments to conduct an appropriate check or control of sports facilities within their jurisdiction. Based on the information thus obtained, Sport England together with the local government will compile the appropriate state database related to sports infrastructure. From this base, the basis for further planning and investment in sports facilities will be formed, within which the school spaces for the realization of the teaching of physical education will be located. This approach will certainly help local governments in the preparation of local development strategies and 
the formation of priorities in the development of sports facilities (Department for Education and Skills, 2002). The relationship with physical education and school sports in England has changed drastically in the 1990s and 2000s in terms of investments made by the central government (Houlihan \& Green, 2006). In this context, former Prime Minister Tony Blair considered physical education and sport important for improving overall education. In 1997 , Tony Blair's government financed the construction and reconstruction of more than 500 schools, through a repayment period of up to 40 years, through an institutional form (Private Finance Initiative - PFI) (The Telegraph, 2017). For Great Britain we can say that it is the country with the largest number of PPP projects in education.

After the volume of investments dropped significantly after the financial crisis in 2009 , Germany has succeeded in re-increasing its share of PPP to almost one billion euros in 2014. Of the total of eight billion euros invested in PPP since 2002, most projects are schools and day centers, but also sports and administrative buildings (Su, Huijie, Yang, \& Ke, 2017). This type of cooperation also implies that private investments are included in the financing of educational institutions. Through the PPP scheme, Germany plans to allocate 52,182,268 euros for capital expenditures (in the period 2010-2013) (of which 7,301,012 euros are intended for school sports). This kind of investment is practiced when the private sector can fulfill the required tasks, at least as good as the state, as this reduces the costs of the public sector (Jacob, Kochendörfer, von Drygalsk, \& Hilbig, 2014).

The Sports Act regulates the financing of sport in the Republic of Croatia with its normative framework. Other legal acts, adopted on the basis of sports laws, also regulate the financing of sports. Funds for financing sports facilities in the Republic of Croatia are realized from public and private sources. The public sector helps to meet public needs in sports. Users of these funds are also institutions dealing with sports infrastructure. Public funds are most often allocated through various sports programs or projects to the relevant Ministries of Sport or to individual local communities. Also, funds are allocated from local funds for projects and programs that are not financed from the state budget. At state level (in the period 2008-2011), total capital investments in sports facilities (including sports halls in primary and secondary schools) amount to more than 370 million Croatian Kuna, while from local sources of financing (for the needs of construction and upgrading of sports facilities) more than a billion Croatian Kuna are invested (Subić, 2016). School sports societies, which are established in schools and care about extracurricular sports activities of students, provide funds for their work from state and local government sources (funds are paid at the expense of the school). In recent years, allocations for sports from state sources have been steadily decreasing, but due to the trend of increasing funds, the investments are maintained at a stable level (despite the economic crisis) (Poslovni dnevnik, 2014). The largest number of projects according to the model of PPP in the Republic of Croatia has so far been achieved in the field of education. In 2014, the Ministry of Science, Education and Sports of the Republic of Croatia envisaged 139 projects that through PPP should improve the quality of educational institutions, of which 18 contracts were signed. An example is the County of Varaždin which, through PPP projects, planned to expand, rebuild, maintain and manage four primary schools. It was calculated that the PPP model is $15 \%$ more favorable than the classic one. The value of the entire project is 107 million Croatian Kuna. The private partner should renew four primary schools within two years. The duration of the contract is 27 years, including two years of preparation and construction. So there remain 25 years of school management and maintenance by a private partner. The state will pay $55 \%$ of the costs, i.e. 
the rent, the county $35 \%$, and the cities and municipalities the remaining $10 \%$ (Poslovni dnevnik, 2014).

In the County of Koprivnica-Križevci, many were dissatisfied with the school building where three different schools were accommodated, with 2,850 students and 85 grades, and the classes were held in three (sometimes four) shifts. The city of Koprivnica was the only local self-government in the Republic of Croatia where no secondary school has been built for over 30 years. The only possibility for the City of Koprivnica was to find a new way of financing the construction of a school through a PPP project where the risk of using, disposing and demanding buildings is transferred from the public sector to the private sector. The fee for school use will be paid by the City of Koprivnica in 286 monthly installments of 700,000 Croatian Kuna. This means that a significant part of the capital budget of the City of Koprivnica remained available for financing other important development and infrastructure projects. In addition, the PPP model has several other advantages: the public partner paid all the services provided, for example, the construction of school kitchen, the same quality of service was provided for a period of 25 years, and the school maintenance standard was established as an obligation of the private partner; the construction of the school was financed without major problems and without a deficit and the maximum public interest was protected. Today, the city of Koprivnica, with its new school, can proudly say that knowledge and expertise were the main driving forces of development in Koprivnica, which is now considered the center where the most suitable conditions for education and the highest quality services in the field of education exist (Poslovni dnevnik, 2014).

In the Republic of Serbia, the management and financing of schools through public revenue sources is a domain of decision-making by the state. In this way, the overall responsibility remains in the domain of the state, that is, the government that manages the budget and therefore determines the basic expenditure in the field of education. This is a fact that is quite understandable and justified, since in the field of compulsory schooling, primary education must be accessible to everyone and free of charge. Having in mind the current economic and financial situation and the lower inflow of budget funds, the schools in the Republic of Serbia are trying to provide an acute shortage of funds through other sources of financing (both domestic and foreign).

In the Republic of Serbia, financing of school sports facilities, investing in construction, renovation, reconstruction and revitalization, equipping and maintenance are most often realized through:

- Realization of revenues from the budget of the Republic of Serbia, its recording and use is carried out in accordance with the regulations governing the budget system. A large part of these funds allocated by the budget goes to the payment of salaries of employees in school (teaching staff and the general sector), social contributions and severance payments.

- Realization of revenues from the budget of the local self-government unit, its recording and use is made in accordance with the participation of the Municipality / City in the area of the school. Units of local self-government, in line with the Law on Local Self-Government (Official Gazette of the Republic of Serbia, 2007), provide funds in the budget for needs and interests.

In the Republic of Serbia, the term PPP in the Serbian legal system was introduced by the Law on PPP and concessions that enabled provincial and local authorities to opt for such a model of financing. The Public Private Partnership Commission was formed by the Decision of the Government of the Republic of Serbia, dated 9 February 2012, published in the Official Gazette of the Republic of Serbia, No. 13/12 of 24 February 2012, and has nine members 
(Public-Private Partnership Commission, 2017). The PPP Commission positively assessed 62 project proposals, of which only 27 received an epilogue in the form of signing contracts between public and private partners. The most contracted projects in the Republic of Serbia are in the public transport, public lighting and energy sectors. Concerning educational institutions, only heating projects were approved (Table 1).

Table 1 List of PPP project proposals in education that received a positive opinion from the PPP Commission

\begin{tabular}{|c|c|c|c|}
\hline Project Name & Proposer & Status & Year \\
\hline $\begin{array}{l}\text { The PPP project proposal, proposing replacement of } \\
\text { existing oil boilers with biomass boilers and contractual } \\
\text { delivery of heat energy in the facilities of Dr Obren Pajić } \\
\text { Dairy School, Sveti Sava Elementary School, Dušan } \\
\text { Radović Elementary School and the Elementary School } 8 \\
\text { September in the municipality of Pirot. }\end{array}$ & $\begin{array}{c}\text { Municipality of } \\
\text { Pirot }\end{array}$ & Agreed & 2017 \\
\hline $\begin{array}{l}\text { Proposal of the PPP project, submitted by the city of Niš } \\
\text { proposing replacement of oil boilers and coal boilers with } \\
\text { wood biomass boilers (pellets) in school and preschool } \\
\text { institutions of the city of Niš with heat energy delivery. }\end{array}$ & City of Niš & $\begin{array}{c}\text { It is not } \\
\text { contracted }\end{array}$ & \\
\hline $\begin{array}{l}\text { The PPP project proposal, submitted by the Faculty of } \\
\text { Economics of the University of Kragujevac, proposing the } \\
\text { construction of its own boiler room, energy recovery and } \\
\text { contractual exclusion of heat energy. }\end{array}$ & $\begin{array}{l}\text { Faculty of } \\
\text { Economics, } \\
\text { University of } \\
\text { Kragujevac }\end{array}$ & $\begin{array}{c}\text { It is not } \\
\text { contracted }\end{array}$ & \\
\hline
\end{tabular}

Source: Vlašković, Žarković, Sredojević, \& Mijačić, 2018

In the upcoming period, PPP projects are expected to be widespread in other areas, especially when it comes to energy efficiency. We have seen that at the European Union level there are numerous examples of PPP projects in education, while in the Republic of Serbia, for now, there are no legal possibilities for the implementation of PPP projects in the construction, upgrading and maintenance of educational institutions (i.e. school sports facilities) (Vlašković, Žarković, Sredojević \& Mijačić, 2018).

\section{DISCUSSION}

The advantages of private sector participation in the construction, maintenance and reconstruction of educational institutions can be reflected in increasing customer service, more efficient use of resources, reducing the costs of public institutions, long-term preservation of quality and value of buildings, increasing the quality of furnishing and maintaining facilities, and creating conditions for one-shift school work. On the other hand, public investments are within the planned budget and deadline, and the pressure on them is reduced, the value for money of taxpayers and end users increases. In 2014, in the new IPA funding cycle, the European Union gave priority to PPP projects, thus motivating local governments to apply for PPP-related projects. The advantage that the European Union has given to these projects requires local governments to activate, identify problems and find partners for their implementation. It is especially important, and well, when PPP projects are used in combination with the financial resources provided by the European Union. Some 
European Union countries have gone a long way in projects to finance the construction and reconstruction of both schools and school sports facilities. As the highest profit, besides the quality of services offered to students, there is also one-shift schoolwork and maintenance of the facilities themselves. A large number of schools, especially school sports facilities that are built and financed by budget funds, quickly lose quality because they lack funds for their regular maintenance.

A survey conducted during the school year 2013/2014 (Subić, 2016) shows that schools in the Republic of Serbia, in terms of financing their needs, primarily rely on funds from the budget of the local self-government unit and the funds of state institutions (Ministry of Education, Science and Technological Development and Ministry of Youth and Sports), as well as donations. When looking at the results of investments in school sports infrastructure from joint funds (joint ventures with a domestic or foreign investor), it can be concluded that they are almost nonexistent. The only investments of this type were in the Srem district, in two schools. One investment was made by the school and the local community in the amount of 370,000 dinars (in 2010), while the second investment was shared by the school, the Ministry of Youth and Sports, the local self-government unit (municipality) and the European Investment Bank in 2009. Fear of the public, of this method of financing, is quite justified. The idea that the state depends on the private owner and the possibility of losing control over the project, in case of unforeseen circumstances or insufficient supervision, and that the entire project is in favor of the private partner, is additionally burdensome to the public. On the other hand, there are different aims, and the public sector should have non-profit goals, while the private sector is exclusively oriented towards profit.

As further factors, we can identify a small number of trained people who know this issue, especially in local governments. Municipalities and cities are usually not sufficiently informed about the ways and possibilities of entering into a partnership with the private sector. As a problem, people in municipalities that are not trained to attract private companies to invest in their local self-government are distinguished. Finding an adequate private partner (whether domestic or foreign) is not an easy task. It is necessary to organize presentations, a quality website, contact with foreign representations and domestic companies in order to find potential partners. The law gave municipalities and cities independence in the decision-making and conduct of such projects, but did not adequately train them in assessing the risk sharing with private partners (Građanske inicijative, 2013). The connection between the state and local selfgovernment must be based on expert assistance and continuous transfer of knowledge from the central to local governments. Most often, the legal regulation of local self-governments is not harmonized with the Law on PPP.

If the law is not clearly defined, gray area without sanctions can also create problems, which can be reflected in financial difficulties. While a contract between the two partners takes place, the public partner pays fixed fee to the private one for the supplied services of the facility at a monthly or annual level. During the duration of the contract, the fee includes the settlement of total costs and other expenditures.

It is very important to emphasize that PPP projects must not have a commercial purpose. The use of the state property must be more favorable and more cost-effective than the traditional model. The public sector must generate additional value and long-term savings for taxpayers. Attention must be paid to the risks that the private partner must take. Risk transfer is one of the most important features. A private partner must take at least two risks, such as: construction risk and availability (or demand). 
The Croatian PPP Law in Article 2 states that during the implementation of PPP projects, the private partner undertakes the obligation and risks related to the financing and construction process from the public one, and at least one of the following two risks: the risk of availability of a public building and the risk of demand. The disadvantage of this provision regarding the obligatory risks that the private partner must assume can endanger the public budget by the occurrence of unplanned expenditures (Zakon, HR, 2018). However, it should not be forgotten that, in addition, the public sector can have major obligations, depending on the method of payment agreed upon by the project. The crisis in England has led the state to intervene and investigate whether and how much the PFI contracts benefit schools. The members of parliament also asked of the Government to take certain steps to ensure that the additional burden on the PFI repayment would not jeopardize the school budget and lead it to a turning point. The biggest burden is the money paid for repairs in schools. Some schools in England are paying thousands of pounds for small utility services or furniture (The Telegraph, 2017). The report of the State Audit Office of Hungary says that projects financed for a period of 20 to 30 years through PPP cost more in terms of net present value, than that the investment was realized through government borrowing (Jokaj, 2010).

We can notice that obstacles to the establishment of such partnerships in Serbia are numerous, from an unwillingness to change the established ways of work, through a lack of understanding of their importance and the lack of information about the results that can be achieved in this way, to insufficient training to achieve such partnerships. We also need to add the discontinuity of the government that does not allow the projects to be implemented fully and completely or that good ideas turn into real jobs for the well-being of citizens. The most common problems that can arise in the construction and reconstruction of school sports facilities are unresolved property-related legal relations (related to land), discrepancy between school construction and prescribed standards, as well as indecision and ignorance of local self-governments, inadequate legal and institutional frameworks and complicated administrative procedure.

\section{CONCLUSION}

The development of school sports infrastructure must be based on clearly defined needs and plans for the development of the entire educational system and sport in the Republic of Serbia. In order to clearly define and implement priorities, the strategic plan envisages that a support network is needed, which includes a whole range of vertically and horizontally linked institutions, various programs and activities. Based on the fact that school sports facilities require large financial investments, the key factor for sustainable development is reflected in the partnership between schools, local governments, sports clubs, federations, and the private sector.

Planning to invest in school sports facilities is an action that demands well defined priorities, formidable choices and self-assessment.

Some of the models of cooperation between the state and the private sector can contribute to the rational and functional construction and equipment of school sports facilities, which will enable them to raise their quality and the quality of teaching.

The tendencies in the development of school sports infrastructure should move in the direction of: 
- aligning the spatial capacities of schools based on well-defined norms of space, equipment and teaching resources in physical education;

- construction, reconstruction and adaptation of space for the realization of physical education in accordance with the needs of teaching, the capacity of the school and the needs of the local community;

- providing space that meets the hygienic and modern conditions for achieving the planned physical activity;

- equipping halls and outdoor gyms in accordance with the contemporary requirements of teaching, new teaching contents and the needs of the users.

In our country, PPP is a new form of financing public services, especially when it comes to school sports facilities. Given that there are schools that do not have the necessary space for the realization of physical education, or that this area is in a very poor condition, provision of funds for school sports facilities is also possible through some kind of PPP that would contribute to savings in the budget, and increase the quality of teaching in the school sports facilities. The need to increase the quality of physical education facilities and the schools themselves, on the one hand, and the increasing reduction of funds in state budgets and local governments, on the other, has led us to explore this method of financing projects in education.

PPP is, above all, a process where it is clearly necessary to analyze whether this model of financing is better than the traditional one and whether it provides better service quality for users for the same money. Other access possibilities need to be clearly identified to achieve similar results and cost estimate for the benefit of the appropriate option. The state should be the one that sets the requirements and the quality of the service that the private partner must maintain. It is therefore necessary that the state keeps control of the activities of the private partner in order to monitor that they are in accordance with the provisions of the contract signed by both partners. It is important that those who deal with this issue in the Republic of Serbia have implemented the procedure and selection of the private partner in a better and more transparent way, with the answer to two key issues:

- Are there better ways to achieve the goal?

- Will the benefit of PPP exceed the costs?

To ensure that PPP starts to exist within the frames of our country, well-formulated laws and strong institutions are needed, as well as support and education of project participants, clear assessment of PPP effects in a joint project, transparency and awareness of stakeholders and society and public information about the effects of PPP project implementation.

We tried to show some aspects of the PPP model with its advantages and disadvantages. It should be seen only as one of the ways and available forms of financing for which we cannot say that it is better or worse than the traditional way. Its future will depend, first and foremost, on the relationship between the state and the economy towards this type of financing of projects and the attitude of society towards this issue.

Cooperation between the state and the private sector can give the Republic of Serbia a certain benefit, which is reflected above all in the following: to unburdening of public budgets of the large-scale investments, solving problems quickly and efficiently, making better use of the current resources, creating the conditions for better education of young people, increasing the quality of school sports facilities and switching to one-shift school work.

Finally, we can conclude that there is space for the legal possibilities for the implementation of PPP projects to be related to education. For this, a more detail research is necessary on the application of PPP in education and its effects on increasing the quality of physical education teaching. 
Acknowledgement: This study is a part of the project III46006 funded by the Ministry of Education, Science and Technological Development of the Republic of Serbia.

\section{REFERENCES}

Alibegović, J.D. (2010). Javno-privatno partnerstvo u Hrvatskoj: Institucionalni okvir i primjeri iz prakse (Public-private partnership in croatia: institutional framework and case studies). In D. Damjanović, T., Pavlović-Križanić, \& G. Peteri (Eds.), Partnerstvo javnog i privatnog sektora: Dobra i loša iskustva u odabranim zemljama u tranziciji (Public and private sector partnerships: Good and bad experiences in selected transition countries) (pp. 47-62). Belgrade: PALGO centar. In Serbian

Biblioteka Narodne skupštine (2011). Javno-privatno partnerstvo i koncesije (Public-private partnerships and concessions). Belgrade: National Assembly Library, National Assembly, Republic of Serbia. Retrieved March 20 2019, from the World Wide Web: http://www.parlament.gov.rs/upload/archive/files/lat/doc/istrazivanja/Javnoprivatno\%20partnerstvo $\% 20 \mathrm{i} \% 20$ koncesije $\% 201$ lat.doc

Department for Education and Skills (2002). A sporting future for all: the role of further and higher education in delivering the Government's plan for sport. London: Department for Culture Media and Sport. Retrieved March 23, 2019, from https://dera.ioe.ac.uk/10138/1/A_sporting_future_for_all.pdf

European Commission (2003). Guidelines for successful public - private partnerships. Bruxelles: European Commission, Directorate-general, Regional Policy. Retrieved March 20, 2019, from https://ec.europa.eu/regional_ policy/sources/docgener/guides/ppp_en.pdf

European Commission (2004). Green paper on Public private partnerships and community law on public contracts and concessions. Bruxelles: EUR-Lex. Retrieved March 20, 2019, from https://eur-lex.europa.eu/legalcontent/EN/TXT/?uri=celex:52004DC0327

Građanske inicijative (2013). Uspešna partnerstva na putu ka EU - Brošura o javno privatnim partnerstvima u Srbiji (Successful Partnerships on the Road to the EU - Brochure on Public Private Partnerships in Serbia). Belgrade: Produkcijska grupa Mreža. Retrieved March 11, 2019, from the World Wide Web: https:/www.gradjanske.org/wpcontent/uploads/2014/10/070-Brosura-o-javno-privatnim-partnerstvima.pdf

HM Treasury (2018). The Green Book. London: Central Government, Guidance on Appraisal and Evaluation. Retrieved March 21, 2019, from https://assets.publishing.service.gov.uk/government/uploads/system/uploads/ attachment_data/file/685903/The_Green_Book.pdf

Houlihan, B., \& Green, M. (2006). The changing status of school sport and physical education: Explaining policy change. Sport Education and Society, 11 (1), 73-92.

Jacob, D., Kochendörfer, B., von Drygalsk, M., \& Hilbig, C. (2014). Ten years of PPP in Germany: experiences and perspectives. Proceedings of the Institution of Civil Engineers-Management, Procurement and Law, 167(4), $180-188$.

Jokaj, Č. (2010). Ocena rizika kod javno-privatnih partnerstava realizovanih u Mađarskoj: Rizici, efikasnost upravljanja i fiskalni odnosi. In D. Damjanović, T., Pavlović-Križanić, \& G. Peteri (Eds.), Partnerstvo javnog i privatnog sektora: Dobra i loša iskustva u odabranim zemljama u tranziciji (pp. 63-88). Belgrade: PALGO centar. In Serbian

Jung, H., Pope, S., \& Kirk, D. (2016). Policy for physical education and school sport in England, 2003-2010: Vested interests and dominant discourses. Physical Education and Sport Pedagogy, 21(5), 501-516.

Matić, M., Bokan, B., Bokan, R., \& Perković, R. (1990). Fizičko vaspitanje: uvod u stručno-teorijsku nadgradnju (Physical education: an introduction to the professional and theoretical superstructure). Belgrade: OKO. In Serbian

Nikolić, S. (2010). Financing School Sports Infrastructure from the National Investment Plan's Assets. In M. Levi Jakšić \& S. Barjaktarović Rakočević (Eds.), 12 International Symposium "Organizational Sciences and Knowledge Management". Belgrade: Faculty of Organizational Sciences, University of Belgrade

Nischwitz, G., \& Andreas, V. (2019). Stadtentwicklungsfonds: Ein neues instrument zur unterstützung nachhaltiger stadtentwicklung? einführung (Urban development fund: A new tool to support sustainable urban development? Introduction). (pp. 3-16). Hannover: Verlag der ARL-Akademie für Raumforschung und Landesplanung. In German

Official Gazette of the Republic of Serbia (2007). Zakon o lokalnoj samoupravi (Law on the Local Government). "S1. glasnik RS", br. 129/2007, 83/2014 - dr. zakon, 101/2016 - dr. zakon, i 47/2018. Belgrade: Ministry of Public Administration and Local Self-Government Retrieved April 11, 2019, from http://mduls.gov.rs/wpcontent/uploads/zakon-o-lokalnoj-samoupravi.docx

Poslovni dnevnik (2014). Javno privatno partnerstvo JPP u Hrvatskoj. Zagreb: Večernji list. Retrieved March 25, 2019, from the World Wide Web: http://www.poslovni.hr/tag/javno-privatno-partnerstvo-jpp-u-hrvatskoj-6810 
Produkcijska grupa Mreža (2013). Javno privatna partnerstva u sportu (Public private partnerships in sport). Retrieved March 25, 2019, from: https://mreza.rs/javno-privatna-partnerstva-u-sportu/

Prokopović, B.B. (2014). Vreme za promenu potrošačkog modela (Time to change the consumer model). Ekonomika, 60(2), 1-8. In Serbian

Public-Private Partnership Commission (2017). Javno-privatno partnerstvo: Komisija za javno-privatno partnerstvo (Public-Private Partnership: Public-Private Partnership Commission). Belgrade: Government of the Republic of Serbia. Retrieved March 25, 2019, from http://jpp.gov.rs/

Sport England (2018). Annual report and accounts. London: The english sports council national lottery distribution fund accounts for the year ended 31 march 2018. Retrieved March 21, 2019, from https://assets.publishing.service.gov. uk/government/uploads/system/uploads/attachment_data/file/723120/CCS0518665748-

1_HC_English_Sports_Council_ARA_2017-18_Web.pdf

Su, G., Huijie, L., Yang, G., \& Ke, G. (2017). The experience and reference on PPP development in Germany. International Journal of Economics, Finance and Management Sciences, 5(6), 327-333.

Subić, S. (2016). Strateški pravci razvoja školske sportske infrastrukture u republici Srbiji u cilju prilagođavanja zahtevima Evropske unije (Strategic directions of school sports infrastructure development in Republic of Serbia in order to adjust to the European Union requirements). Doctoral dissertation, Belgrade: Faculty of Organizational Sciences, University of Belgrade. Retrieved December 10, 2018, from http://nardus.mpn.gov.rs/ handle/123456789/7026

Šuput, D. (2009). Zakonsko uređivanje sporta u evropskim državama (National Laws Regulating Sports in European Countries). Strani pravni život, 3, 247-272. In Serbian

Terzić, S. (2013). Uloga i značaj javno-privatnog partnerstva (The role and importance of public-private partnership). Svarog, 1(7), 305-317. In Serbian

The Telegraph (2017). Education. London: By Harry Yorke, Online Education Editor. Retrieved March 22, 2019, from the World Wide Web: https://www.telegraph.co.uk/education/2017/04/21/hundreds-schools-held-hostage-pficontracts-investigation-reveals/

Vlašković, V., Žarković, J., Sredojević, S., \& Mijačić, D. (2018). U susret EU integracijama - Unapređenje pravnog $i$ institucialnog okvira javno-privatnog partnerstva u Srbiji (Towards EU integration - improving the legal and institutional framework of public-private partnership in Serbia). Belgrade: Institute for Territorial Economic Development (InTER). In Serbian

Zakon, HR (2018). Zakon o javno-privatnom partnerstvu (Public-private partnership act). Zagreb: Zakon. HR. Retrieved March 12, 2019, from the World Wide Web: https://www.zakon.hr/cms.htm?id=899

Zrnzević, N., \& Zrnzević, J. (2018). Programmed physical education teaching and its effects on students'motor skills. Facta Universitatis Series Physical Education and Sport, 15(3), 501-512.

\section{JAVNO PRIVATNO PARTNERSTVO U FUNKCIJI POVEĆANjA KVALITETA ŠKOLSKIH SPORTSKIH OBJEKATA}

Cilj rada je da se ukaže da je za održiv razvoj školske sportske infrastrukture neophodno stvoriti uslove koji treba da budu jasno definisani u međusobnim pravima i obavezama svih učesnika u procesu izgradnje, korišćenja i održavanja. To bi se ostvarilo uz pomoć javno partnerskih odnosa između države $i$ privatnog sektora. Ovaj rad se temelji na iskustvima nekih od zemalja Evropske unije, koje su probleme izgradnje, dogradnje, opremanja i održavanja školskih sportskih objekata rešile kroz projekte javnoprivatnog partnerstva, na zakonskim regulativama sadržanim $u$ zelenoj knjizi o javnom privatnom partnerstvu, kao i zakonu o javnom privatnom partnerstvu i koncesijama u Republici Srbiji. Svakako, želja da se unapredi kvalitet obrazovnih usluga, sa jedne starne i nedostatak novca u budžetima centralnih $i$ lokalnih vlasti, sa druge strane, nameće potrebu istraživanja ovog vida poslovne saradnje i finasiranja projekata. $U$ radu se daje osvrt $i$ na složenost implementacije javno privatnog partnerstva $u$ tradicionalnim obrazovnim okvirima, zbog složenosti odnosa između dva partnera koji nameću različite interese.

Ključne reči: školski sportski objekti, javno privatno partnerstvo, Evropska unija, Republika Srbija 